\title{
Juridical Overview of the Crime of Terrorism in Indonesia
}

\author{
Sigit Karyadi ${ }^{1}$, Suparno ${ }^{2}$ \\ \{SigitkaryadiS2@gmail.com ${ }^{1}$, suparno@borobudur.ac.id ${ }^{2}$ \} \\ Universitas Borobudur, Jakarta, Indonesia ${ }^{1,2}$
}

\begin{abstract}
Terrorism is one of the things that affect national stability. Terrorist acts in Indonesia have increased over the years, disturbing the nation's peace. The series of bombings on the territory of the Republic of Indonesia has sparked widespread terror in the society, resulting in the loss of life and property, and has harmed Indonesia's social, economic, political, and international connections. Terrorism employs a variety of methods to carry out such attacks, whereas bombing has grown commonplace in a number of nations. With a literature review methodology and laws connected to criminal acts of terrorism in Indonesia, this research technique is normative juridical. The findings of this research are connected to the aspects of criminal activities in acts of terrorism, which are classified as crimes that go beyond humanity's bounds. As a result, with order to combat terrorism-related illegal crimes in Indonesia, it is important to strictly execute criminal legislation.
\end{abstract}

Keywords: Crime; Terrorism; Attack; Law Enforcement

\section{Introduction}

The ideals of the Indonesian people are to prove the Indonesian nation and all of Indonesia's blood bleeds, promote public welfare, educate the country's life, and contribute to the establishment of a world order based on independence, enduring peace, and social justice, as stated in the Preamble to the 1945 Constitution of the Republic of Indonesia (hereinafter referred to as the 1945 Constitution of the Republic of Indonesia).[1] It is vital to prevent things that disrupt national stability in order to attain these goals and ensure the continuation of national development in a safe, peaceful, and dynamic environment, both on a national and international level.[2]

Terrorism is one of the things that threatens national stability. Terrorist attacks have become more common in Indonesia in recent years, shocking the country's tranquility.[3] The sequence of bombings on the territory of the Unitary State of the Republic of Indonesia has sparked widespread public terror and resulted in the loss of life and property, wreaking havoc on Indonesia's social, economic, political, and international ties.[4] Explosions of bombs are one sort of terrorism that has grown increasingly common in several nations. Terrorism is a large criminal operation that threatens national and international peace and security. It is transnational, organized, and even multinational.[5] 
Indonesia as a state of the law as mandated by the 1945 Constitution in article 1 paragraph (3) emphasises that the state and government must always be based on the law in all aspects of life in society. In crime, the Criminal Code (KUHP) is the primary source of reference for criminal law. Many criminal experts argue that the Criminal Code can be used as a legal basis for terrorism crimes. However, it is proven that the Criminal Code is not functioning effectively for law enforcement in Indonesia. Under this pressure, the Government Regulation in place of Law No. 1 of 2002 and Perpu No. 2 of 2002, as the predecessor to the birth of Law No. 15 of 2003 concerning the elimination of criminal acts of terrorism, which was to cope with the Bali bombing tragedy at the time, was enacted.[6]

The birth of the two Perpu, ratified into the Terrorism Crime Act, raises pros and cons. Some argue that the terrorist offense statute is in violation of criminal law principles. Even if terrorism is an uncommon crime (extraordinary crime) and a crime against humanity (crime against humanity), they argue that this is insufficient justification to apply the law retrospectively. From a political perspective, it is feared that the terrorism law is only intended for certain groups, primarily Islamic fundamentalists who radically criticise government policies.

In early January 2016, the Indonesian capital was again shocked by acts of terrorism. A series of explosions and shootings occurred in the MH Thamrin area. Responding to the bombings and attacks in the Sarinah area, the government, It would adopt policy initiatives linked to national legal politics, according to Coordinating Minister for Political, Legal, and Security Affairs Luhut Binsar PandjaitanFinally, President Joko Widodo chose to bolster measures to combat terrorism by rewriting Law No. 15 of 2003 on the Prevention of Terrorist Acts. At the end of January 2016, the government then finalised the Draft Law on Combating terrorism and in February 2016, the government officially submitted the draft to the DPR.

On Thursday (21/6/2018) in Jakarta, it was decided to enact Law (UU) No. 5 of the Republic of Indonesia. 2018 about amendments to Law No. 15 of 2003 concerning the establishment of government regulations in lieu of Law No. 1 of 2002 regarding the abolition of terrorism-related criminal acts, with the joint approval of the House of Representatives of the Republic of Indonesia (DPR RI) and the President of the Republic of Indonesia.

Article 6 of Law No. 5 of 2018 contains the following provisions on the punishments imposed on terrorist convicts:

Any person who intentionally uses or threatens to use violence or threats of violence to create a climate of fear and panic among the public, causing mass casualties by seizing freedom or causing damage or destruction to Strategic Vital Objects, the environment, public facilities, or international facilities shall be punished by imprisonment for a minimum of five years and a maximum of twenty years, life imprisonment, or the death penalty.[7]

According to affirmative legislation based on Regulation Number 5 of 2018 regarding Amendments to Act Number 15 of 2003 respecting the Anti-Terrorism Law, the penalties for the Criminal Act of Terrorism are the least minimum imprisonment for five years. The death penalty or life imprisonment is the most severe penalty, with a maximum sentence of 20 years.

The importance of good law in the eradication of criminal acts of terrorism is based on the theory put forward by Friedman M. Lawrence, "that the primary key that is very decisive in the context of law enforcement is the legal substance, in addition to the legal structure and legal culture. Legal culture). The structure concerns law enforcement officers and their facilities and infrastructure, then the substance includes legislation, and legal culture is a living law that is adhered to in a society.

Combating criminal acts of terrorism is certainly not enough to issue various regulations or policies related to these efforts.[8] Still, another important thing that needs to be considered is 
the Indonesian National Police (Polri) institution, which is the front line in disclosing various acts of terrorism that occur. In Indonesia, The National Police strives to accomplish domestic security, which includes preserving general security and order, order, and law enforcement, as one of the state government's tasks in the areas of security and public order, law enforcement, protection, shelter, and community service. Protection, protection, and service to the community, as well as the maintenance of public peace via the enforcement of human rights.[9]

Based on the Decree of the National Police Chief Number: Kep/30/VI/2003, dated June 30, 2003, concerning the Organization and Work Procedures of Organizational Units at the Level of the Indonesian National Police Headquarters, which has subsequently been amended through the Regulation of the National Police Chief Number 21 of 2010 concerning Organisational Structure and Work Procedures of Organizational Units at the Headquarters Level of the Indonesian National Police, the authority to uncover criminal acts of terrorism rests with the Special Detachment 88 Anti-Terror unit (Densus 88 AT Polri).[3]

After the Special Detachment 88 Anti-Terrorism Unit of the Indonesian National Police (abbreviated as Densus 88 AT Polri) was formed, more and more terrorism crimes were revealed. Many terrorist kingpins were arrested and sentenced by the courts, but efforts to overcome various criminal acts. This terrorism seems unable to stop because there are still many terrorist events that have occurred until now. In this regard, to conduct a more comprehensive and methodologically accountable analysis of the problem.

\section{Methods}

This study used normative-empirical legal research, which is legal research focused on the enforcement or execution of normative legal provisions in action on specific legal occurrences in society. There is a legal evaluation of terrorism-related criminal activities in Indonesia.[10] This study was written using a juridical-empirical method that used secondary and primary data from books, legal literature, legislation, interviews, and other sources. This normativeempirical method combines the normative legal procedure with a variety of empirical components.

The sorts of data utilized in this study are classified into two categories in order to collect the right data for discussing this article and following the issue strategy employed in this investigation. Secondary data is data received or collected through literature/library studies by collecting data such as laws and regulations, fiqh, and other literature books. Primary data is data obtained directly from the field through interviews with the National Counterterrorism Agency, and Secondary data is data received or collected through literature/library studies by collecting data such as laws and regulations, fiqh, and other literature books.[11]

\section{Discussion}

\subsection{Elements of the Crime of Terrorism}

Terrorism is a component of a larger crime that cannot be defined as ordinary. Terrorism is classified as an unusual crime and a crime against humanity in academic circles. Terrorism is a crime against state security on the legal level; as such, it cannot be eradicated using the same means used to combat regular crimes like theft, murder, or maltreatment. Terrorism is a type 
of crime that jeopardizes the security and sovereignty of the Republic of Indonesia's Unitary State (NKRI).

"Criminal actions of terrorism are acts that fulfill the components of a criminal act in accordance with the requirements of this law," according to Article 1 point 1 of Law Number 15 of 2003. The components of criminal acts of terrorism, as defined by Law Number 15 of 2003 , will be described first, followed by offenses connected to criminal acts of terrorism. The elements of criminal acts of terrorism in Article 6, namely:

1. Deliberately;

2. Using violence or threats of violence;

3. Creating a widespread environment of panic or fear among the public, or inflicting mass fatalities by depriving others of their liberty or suffering loss of life and property; and

4. causing destruction or damage to critical strategic items, the environment, public facilities, or international facilities

From the formulation of Article 6, which reads: "...deliberately employing violence or threats of violence to create a widespread environment of panic or fear, or to inflict mass fatalities...," indicates that the article is formulated "materially". So what is prohibited is "consequences", namely the emergence of an atmosphere of terror or fear or the emergence of mass victims. With the formulation as a material offence, what needs to be proven is an "effect", namely:

1. To create an atmosphere of terror or fear of people widely;

2. Cause mass victims by depriving liberty or loss of life and property of others; and

3. He is causing damage or destruction to vital strategic objects, the environment, public facilities, or international facilities.

The consequences above have a causal relationship with the perpetrators' actions who intentionally use violence or threats of violence. In criminal law theory, to determine causality, there are 3 (three) streams, namely:

1. Equivalence Theory. This theory says that every condition is a cause, and all states are equal in value. Because if one situation does not exist, then the result will be different. Every positive and negative condition for the emergence of an effect is a cause and has the same value. If one state is omitted, there will be no concrete consequences, as is the case according to the time and place of the situation.

2. Individualisation Theory. This theory chooses post-factum (inconcreto). After a concrete event occurs, the most decisive cause of the event is selected from a series of active and passive factors. At the same time, other factors are only conditions. This theory reviews concretely about some instances only and from a series of causes that have given rise to effects, looking for the most decisive reasons for the occurrence of the impact under certain circumstances.

3. Generalisation Theory. This theory looks at ante factum (before the incident / in the abstract) whether there are human actions that in general can cause such consequences among the series of conditions. That is, according to ordinary life experience or according to a proper calculation, there is a chance for it. In this theory, an adequate cause is sought for effect (ad-acquare means made equal). Therefore, this theory is called good theory (adequate theory, adaquanzttheorie).

The definition of the elements of the formulation of Article 6 of Law Number 15 of 2003 can be interpreted as follows:

1. Elements of violence or threats of violence. What is meant by "violence" according to Article 1 point 4 is an act of abusing physical strength with or without using means that is against the law and poses a danger to the body, life, and independence of people, including 
making people faint or helpless. Meanwhile, what is meant by "threats of violence" according to Article 1 point 5 is any act intentionally carried out to give a sign or warning regarding a situation that tends to cause fear to people or society at large.

2. Other elements. Creating an atmosphere of terror or fear of people widely or causing mass casualties. The definition of the elements in question are:

a. Terror. Law Number 15 of 2003 does not explain what is meant by terror. Based on the interpretation of language, namely according to the Big Indonesian Dictionary, terror has the meaning as "Efforts to create fear, horror, and cruelty by a person or group.

b. Afraid. According to the Big Indonesian Dictionary, when using language interpretation, the word fear means "feeling trepidation (horrified) to face something that is considered a disaster.

c. Expanding. According to the Big Indonesian Dictionary, developing means developing (a lot, etc.); or evenly."

d. Object of strategic importance. Critical strategic items, according to Article 1 point 10, are sites, locations, or buildings with extremely high economic, political, social, cultural, defense, or security importance, including international facilities.

e. Public facility. According to Article 1 point 11, what is meant by public facilities are places used for the benefit of the public in general.

f. Environmental damage or destruction. According to the explanation of Article 6, what is meant by environmental damage or destruction is the contamination or destruction of the unity of space with all objects, forces, conditions, and living things, including humans and their behaviour, which affects the continuity of life and the welfare of humans and other creatures. Including damaging or destroying is intentionally releasing or dumping substances, energy, and other harmful or toxic components into the ground, air or surface water detrimental to people or goods.

The scope of the criminal act of assistance expands beyond what is determined under the Criminal Code. It includes the people involved and contributing in such a way apart from being directly involved in the execution of the crime. It is essential to expand the scope of criminal acts of assistance in countering terrorism to combat modern terrorism. Terrorist cells can plan criminal acts of terrorism and help terrorists avoid detection from the security forces. The stipulation of conspiracy, trial, and assistance to commit acts of terrorism as referred to in Article 6, Article 7, Article 8, Article 9, Article 10, Article 11, and Article 12 as an independent crime and shall be punished with the same punishment as perpetrators of terrorism. This is a new arrangement and is different from the existing collections in the Criminal Code, where the criminal threat for parties guilty of conducting an experiment (Article 53 of the Criminal Code) or assistance (Article 57 of the Criminal Code) is reduced by one third and if the crime is punishable by death or life imprisonment, sentenced to a maximum imprisonment of (15) fifteen years.

Meanwhile, conspiracy to cause fire, explosion, or flood is only subject to a maximum imprisonment of (5) five years in Article 187 of the Criminal Code. The Regulation regarding the punishment of conspiracy, trial, and assistance to commit a criminal act of terrorism which is equated with the perpetrator of a criminal act of terrorism, shows that the legislators consider the criminal act of terrorism as referred to in the articles above as a criminal act which is very dangerous for the people-legal interest in both people and property.

3.2 The form of Protection from The Employment Social Security Administering Body in Protecting Workers Who Experience Accidents while Working 
Efforts to reform Law Number 15 of 2003 concerning the Crime of Terrorism are also continuously being carried out by the government and related elements, and this can be seen in consideration of the Draft Law on Amendments to the law on the Crime of Terrorism, which states that for more guaranteeing legal certainty and avoiding diversity of interpretations in law enforcement as well as providing protection and fair treatment to the public to prevent and eradicate terrorism, it is necessary to amend Law Number 15 of 2003 concerning the Eradication of Criminal Acts of Terrorism.

Observing the contents of the Draft Law on Amendments to the Criminal Act of Terrorism, it is seen that the issue of punishment still maintains a minimum criminal threat specifically for terrorism crimes. Still, there are no rules/guidelines for its application. The point of detention of terrorism suspects has also remained unchanged, even though the issue of incarceration is the most decisive legal process for terrorism suspects, even so far, the public has only seen the results that the police have succeeded in capturing and uncovering terrorism networks and bringing them to justice, but do not see the difficulties faced. Officers in the field because of the limited time of detention.

Based on the practical experience of Detachment 88 AT Polri, it turns out that arresting terrorist networks in the usual way that refers to the Criminal Procedure Code will complicate the following arrest process. There can be proven by the time interval between one group's arrest, and another group takes 2 (two) months or more. The subsequent arrest process takes even longer because the terrorist suspect network also learns the pattern of arresting their comrades.

To prevent and overcome theoretic crimes utilising a penal, the functionalisation/operationalisation is carried out through: (1) the policy development stage (legislative policy); 2) the policy application stage (judicial policy); and 3) the policy implementation stage (administrative policy). The formulation stage, also known as legislative policy, is the most important step, which involves lawmakers enacting laws and regulations. Every legal regulation enacted should address every societal need and circumstance.

The legislative policy stage is the most important because it produces a legal regulation that will act as a guide for the legal policy process's subsequent phases. The level of formulation is the legislative product known as this statute at the level of legal policy. Its stance is abstract (in the form of regulations/laws), implying that if applied in practice, this legislation will have significance. As a result, in order for laws to be implemented in society, entities termed executive bodies in law/political science are required. Independent judicial entities/judicial bodies, on the other hand, are entrusted with executing or making laws and regulations effective. Also, it's neutral and unaffected by other bodies.

The formulation/legislative policy is also related to the issue of penitents, which is an integral part of sentencing policy. According to Herbert L. Parker is one of the controversial issues in criminal law.[12] Legislation policy as one part of the functionalisation/operationalisation of illegal law policies in the prevention and control of criminal acts is inseparable from efforts to provide protection and justice for victims of crime.

Legislation policy is the most strategic stage of crime prevention efforts using penal means. It is called strategic because guidelines are set for implementing the following stages, namely the application and execution stages. In other words, mistakes in making a formulation of legislation will harm the operationalisation of the application and execution of these regulations. The formulation stage is also called law enforcement in abstract by the legislature as an institution that can formulate policies.

Implementing law enforcement based on Law no. 8 of 1981 (KUHAP) is imperatively a systematic and mutually integrated effort. The integration referred to in the enforcement of 
criminal law is an affirmation of the criminal justice system, which means an integrated opinion, attitude, and steps towards preventing and eradicating crime in a society. Each component in the criminal justice process can't eliminate crimes that occur if they only prioritise the interests of their institutions without coordinating and seeing the most significant appeals of a system. Each component is a sub-system within the overall criminal justice system.

In an integrated criminal justice system, the operation of the sub-system must be integrated (integrated) with other sub-systems. There must be a common perception in understanding the criminal law issues while still seeing the primary purpose of the criminal justice system. If there is incoherence from the beginning, it is confident that the system's operation as a means of criminal law will fail, which will lose public trust in the sub-system as a whole.

Given the complexity of the workload of Polri investigators, other knowledge is needed as a tool to achieve success. Science as a tool in question is the science of investigative management. The need for investigative management knowledge to support the success of Polri investigators in carrying out investigative tasks, conceptually it already exists and is developed within the Polri environment. Still, in practice, it is sometimes constrained by the specifications of the criminal acts being investigated, such as criminal acts of environmental pollution, corruption, terrorism, and others. The management of this investigation needs to be controlled by every member of the Detachment 88 AT Polri because:

a. the period of detention carried out by investigators is limited and limited;

b. the number of cases or cases that are accepted by the police and cannot be rejected;

c. the human resources of the National Police are still low and inconsistent;

d. the budget required and spent is quite prominent in the investigation process; and

e. Police facilities and infrastructure are limited.

The detention time limit stipulated in the Criminal Procedure Code is different from Perpu No. 1 of 2002. The detention period of terrorist suspects, according to Perpu No. 1 of 2002, is longer than the Criminal Procedure Code. Considering that it is pretty difficult to prove the crime of terrorism, the length of detention must be understood by law enforcement. Perpu No. 1 of 2002 as a legal umbrella for criminal acts of terrorism, besides maintaining the paradigm of protecting the rights of suspects, they must also protect the human rights of victims.

According to Article 1 point 13 of Law No. 2 of 2002, an investigation is a sequence of acts taken by an investigator in accordance with and according to the procedure prescribed by law in order to seek and gather evidence that demonstrates the criminal conduct that happened and to locate the suspect.Thus, essentially the function of the investigation is to make clear an action/deed so that it can be concluded that the act has indeed fulfilled the elements to be called a criminal act and to make it clear that the person who committed the act can be suspected of having committed a criminal act, according to the evidence collected.

Talking about criminal acts in general, the investigation process is carried out based on the rules set out in the Criminal Procedure Code. Still, specifically for criminal acts of terrorism, apart from referring to the Criminal Procedure Code, the provisions regarding investigations used as guidelines are Perpu No. 1 of 2002 as stipulated into law based on Law no. 15 of 2003. There is stated in Article 25 of Perpu No. 1 of 2002 that investigations, prosecutions and examinations in court proceedings in cases of criminal acts of terrorism are carried out based on the applicable procedural law unless otherwise stipulated in this Government Regulation instead of Law. Furthermore, it is also stated that investigators can detain the suspect for a maximum of four months during the investigation process.

Investigations into criminal acts of terrorism can be started if sufficient preliminary evidence can be obtained from each intelligence report. Still, based on Article 26 of Perpu no. 
1 of 2002 , it is stated that the determination has been accepted or sufficient preliminary evidence must be carried out by the Chairman or Deputy Chairperson of the District Court, which is carried out in private within a maximum of 3 (three), while Article 28 states that investigators can make arrests against any person who is strongly suspected of committing a criminal act of terrorism based on sufficient preliminary evidence within a maximum period of 7 x 24 (seven times twenty-four) hours. Evidence for examining criminal acts of terrorism as stated in Article 27 of Perpu No. 1 of 2002, consisting of;

1. evidence as defined by the Criminal Procedure Code;

2. other evidence in the form of information that is spoken, sent, received, or stored electronically with optical devices or similar devices;

3. data, recordings, or information that can be seen, read, or heard and that may be issued with or without the use of a method, whether written on paper, on any physical item other than paper, or electronically recorded, including but not limited to: text, music, or picture; maps, designs, or photos; People who can read or interpret letters, signs, numbers, symbols, or perforations have meaning or can understand them.

Terrorists' assets can be frozen under Article 29 of Perpu No. 1 of 2002, which states that investigators, public prosecutors, or judges have the authority to order banks and financial service institutions to freeze the assets of anyone who is known or reasonably suspected of being the proceeds of terrorism or terrorism-related crimes. The blocking order must be in writing, and it must explicitly state:

a. the name and position of the investigator, public prosecutor, or judge;

b. the identity of each person who banks and financial service institutions have reported to investigators, suspects, or defendants;

c. reason for blocking;

d. a criminal act that is suspected or charged; and

e. where the wealth is located.

Based on their knowledge and skills and the authority and function of the Detachment 88 AT Police Investigation Division, the Investigating Officers in the Police Detachment 88 AT Investigation Division have been able to uncover cases of criminal acts of terrorism with radical groups. Disclosure of this case is carried out according to the authorities stipulated in Article 7 of the Criminal Code, among others, by carrying out examinations at the crime scene (TKP), making arrests, detentions, and searches confiscations as well as examining witnesses.

Observing the contents of the Draft Law on Amendments to the Criminal Act of Terrorism, it is seen that the issue of punishment still maintains a minimum criminal threat specifically for terrorism crimes. Still, there are no rules/guidelines for its application. The point of detention of terrorism suspects has also remained unchanged, even though the issue of imprisonment is the most decisive legal process for terrorism suspects, even so far, the public has only seen the results that the police have succeeded in capturing and uncovering terrorism networks and bringing them to justice, but do not see the difficulties faced. Officers in the field because of the limited time of detention.

One of the keys to the success of the investigators at the Detachment 88 AT Polri is to uncover cases of criminal acts of terrorism by radical groups, apart from the fact that the personnel of Detachment 88 AT Polri are police officers who have been trained to uncover criminal acts of terrorism, also because based on the results of the examination at the crime scene, several items were found. Evidence in the form of equipment and materials for making bombs, firearms and no less critical is based on the statements obtained from the witnesses examined by the investigators of Densus 88 AT Polri. 


\section{Conclusion}

Any person who commits a malicious conspiracy, attempt, or assistance to commit an illegal act of financing terrorism, intentionally provides, collects, gives, or lends funds either directly or indirectly, intending to be used wholly or partly to commit acts of terrorism, terrorist organizations, or terrorists, is committing a criminal act of financing terrorism. With these elements, the legal condition of a person is determined regarding whether the legal subject has committed a crime or not. In the instance of a criminal act of terrorist funding, the legal issue can be said to have committed an act of funding terrorism acts if the legal subject has met the requirements of criminal law both objectively as well as subjective.

From the perspective of law enforcement officers, it appears that members (personnel) of Densus 88 AT Polri who are in charge of conducting investigations and investigations of criminal acts of terrorism perpetrated by radical groups are because members (personnel) of Densus 88 AT Polri who are already trained and experienced in their duties, so that the case disclosure does not face obstacles or significant obstacles, and from the results of the investigation carried out.

\section{References}

[1] J. Striegher, "The Deradicalisation of Terrorists," Salus J., vol. 1, no. 1, pp. 19-40, 2013.

[2] A. N. Guiora, Cybersecurity: geopolitics, law, and policy. 2017.

[3] E. E. Supriyanto, M. Rachmawati, and F. J. Nugroho, "Transformative Policies and Infrastructure Strengthening Towards the Police Era 4 . 0," J. Bina Praja, vol. 13, pp. 231-243, 2021.

[4] J. G. Horgan and J. Horgan, The psychology of terrorism. Routledge, 2004.

[5] F. Dallmayr, M. A. Kayapinar, and I. Yaylaci, Civilization and World Order: Geopolitics and Cultural Difference. Plymouth: Lexington Press, 2014.

[6] J. Indrawan and M. P. Aji, "Efektivitas Program Deradikalisasi Badan Nasional Penanggulangan Terorisme Terhadap Narapidana Terorisme Di Indonesia," $J$. Pertahanan Bela Negara, vol. 9, no. 2, p. 1, 2019, doi: 10.33172/jpbh.v9i2.561.

[7] BNPT, Peraturan Kepala BNPT No. Per-03/K.BNPT/1/2017 Tentang Pedoman Umum Forum koordinasi Pencegahan Terorisme. 2017.

[8] B. L. Campbell, "Sergeants as Leaders: A Case Study of Transformational Leadership Among First-Line Supervisors in the Police Department," 2011.

[9] E. I. Heri, "Tantangan Pengembangan SDM Polri di Era Revolusi Industri 4.0," Ilmu Kepol., vol. 13, no. 2, pp. 90-105, 2019, [Online]. Available: www.jurnalptik.id.

[10] J. J. Little, "Cognitive load theory and library research guides," Internet Ref. Serv. Q., vol. 15, no. 1, pp. 53-63, 2010, doi: 10.1080/10875300903530199.

[11] D. Lee, "Research consultations: Enhancing library research skills," Ref. Libr., vol. 41, no. 85, pp. 169-180, 2004, doi: 10.1300/J120v41n85_13.

[12] L. Parker, "The Experience of Adolescent Students In Modernist Islamic Boarding Schools in West Sumatra, Indonesia," 17th Bienn. Conf. Asian Stud. Assoc. Aust., no. July, pp. 1-19, 2008. 
